\title{
How mismatching institutional logics hinder niche-regime interaction and how boundary spanners intervene
}

\author{
Magda Smink*, Simona O. Negro, Eva Niesten, Marko P. Hekkert \\ Utrecht University, Copernicus Institute of Sustainable Development and Innovation, Department of Innovation Studies, Heidelberglaan 2, 3584 CS Utrecht, The Netherlands
}

\section{A R T I C L E I N F O}

\section{Article history:}

Received 8 January 2014

Received in revised form 30 June 2015

Accepted 2 July 2015

Available online 28 July 2015

\section{Keywords:}

Sustainability transitions

Niche-regime interaction

Institutional logics

Boundary spanning

Biomethane

Gas network

\begin{abstract}
A B S T R A C T
The promotion of renewable energy production requires the cooperation of previously unrelated actors. In the Netherlands, a government subsidy pushes biomethane producers into a relationship with operators of the gas network. However, this cooperation proved to be very difficult. This research analyzes the problematic interaction between producers and network operators in the case of biomethane injection in the Dutch natural gas grid. We draw on the concept of 'institutional logics' to improve our understanding of this interaction and to identify divergent practices and belief systems. This research contributes to the multilevel perspective on socio-technical transitions, in particular to insights into the interaction between the biomethane niche and gas regime. Based on interviews and secondary data sources we find diverging logics for biomethane producers and network operators. The differences regarding the goals pursued, decisionmaking style, and the scale of operations hamper productive cooperation. We also observe that "boundary spanning' individuals step in to increase mutual understanding and to forge productive working relationships. However, the existing logics leave very little room for maneuvering, given the embeddedness and stability of logics in thinking, acting, and physical infrastructure. Mismatching institutional logics form a serious hurdle for successful biomethane injection, and thus hinder the transition towards more renewable energy production.
\end{abstract}

(c) 2015 Elsevier Inc. All rights reserved.

\section{Introduction}

Since 2008, the Dutch government subsidizes the production of biomethane and injection of this renewable gas into the natural gas grid. In an effort to meet the EU renewable energy target of $14 \%$ in 2020 in a cost-efficient way, the government has sharply increased the subsidy budget for biomethane production and injection to 1 billion euros, or $2 / 3$ of the total budget for renewable energy production in 2011 (RVO, 2012). This subsidy encourages the food and agricultural sector to produce biogas, upgrade it to biomethane and inject it into the natural gas infrastructure. Thus, biomethane producers are pushed into a relationship with operators of the gas network. However, these two types of actors did not deal with each other before and come from very different worlds. Cooperation between the producers and network operators proved very difficult: only $13 \%$ of the proposed biomethane production capacity that was allocated subsidy in 2011 has been realized (RVO, 2014: 53). Therefore, the promotion of renewable energy technologies that requires the cooperation of previously unrelated actors merits further attention. Insights into interaction between different types of actors will enable the transition to more

\footnotetext{
* Corresponding author.

E-mail address: magdasmink@gmail.com (M. Smink).
}

renewable energy production. In this research, we set out to map the problematic interaction between biomethane producers and network operators, and to describe the way in which these problems are addressed.

The interaction between biomethane producers and network operators can be conceptualized as an interaction between niche actors and regime actors, respectively. The interaction between niches and regimes is central to the process of societal transitions (Geels, 2002; van den Bergh et al., 2011). A niche is supposed to expand to the point where it is strong enough to break through and substitute or transform parts of the regime. However, several authors have pointed out that the exact form of this interaction between niche and regime has received insufficient attention (Smith, 2007; Elzen et al., 2012a,b; Diaz et al., 2013). As Diaz et al. (2013) state: 'initiating a transition is not a matter of simply 'scaling-up' a technology that has been developed in a niche, but is a complex and often messy process' (p. 63). This knowledge gap at the heart of transition theory needs to be urgently addressed.

So far, most multi-level-perspective case studies describe the indirect interaction between a niche and a regime, e.g. through changes in relative prices or policy (e.g. Raven, 2004; Raven and Verbong, 2009). This indirect interaction is also expressed by the fact that niche, regime and landscape developments are often presented in separate sections (e.g. Geels, 2002, 2005, 2006, 2007; Verbong and Geels, 2007). Few case studies focus on niche-regime interactions where actors have to 
cooperate directly, bringing about a real confrontation (cf. Raven, 2007 on symbiotic multi-regime interaction).

A few examples of these case studies include those by Smith (2007), Elzen et al. (2012a,b), and Diaz et al. (2013). Smith (2007) provides an analysis of niche-regime interaction in the housing sector; Elzen et al. (2012a) study innovation in the horticulture sector; whereas Elzen et al. (2012b) and Diaz et al. (2013) investigate transitions in farming. Each of these studies focuses on the social interaction between niche and regime, on how niches manage to establish links with and influence the regime and thus show the complexity of up scaling. In addition, Wirth et al. (2013) specifically address the culture-gap by studying the role of regional professional cultures in explaining spatial variety in diffusion of biogas installations. An important phenomenon in these studies is the presence of actors that actively facilitate communication and cooperation between niche and regime actors (Elzen et al., 2012a, b; Diaz et al., 2013).

Despite the fact that some work has been done on this issue, a deeper insight in how niches interact with regimes is necessary. A specific knowledge gap remains with regard to physical infrastructure: a core element of regimes (Loorbach et al., 2010). In the context of the water sector, Lieberherr and Truffer (2015) call them the 'gate-keepers for the introduction of any novelty in the sector' (p. 2). Especially the gas infrastructure has been under researched (with the notable exception of Arapostathis et al., 2013, 2014). Certain niches depend on existing infrastructure, such as electricity and gas networks, for their operation (cf. Goldthau, 2014). As niches grow, access to infrastructure becomes increasingly important (van der Vooren et al., 2012; van der Vooren and Alkemade, 2012). However, the material and long-term nature of regime infrastructure make accommodations extremely difficult (cf. Markard, 2011). Therefore, focusing on niche interaction with a regime characterized by rigidity will teach us about a core element of the transition problem: how the most stable arrangements can or cannot be transformed (cf. Fuenfschilling and Truffer, 2014).

A key problem for the uptake of niches in the regime is that they each operate according to a different set of rules and routines (Rip and Kemp, 1998; Geels, 2004; Fuenfschilling and Truffer, 2014), and thus a different set of institutions (Elzen et al., 2012a).

Given our focus on the role of infrastructure in transition processes, we need a theoretical approach on institutions that includes both social and material elements. The institutional logics approach (e.g. Thornton and Ocasio, 2008) emphasizes that institutions have both symbolic and material elements, and recognizes that these are 'intertwined and constitutive of one another' (Thornton et al., 2012: 10). This combination of social and material elements matches with the alignment of social and technical elements in a socio-technical regime (Fuenfschilling and Truffer, 2014). Institutional logics are the practices and underlying belief systems that guide actors' behavior and thinking. 'How actors make sense of and act upon reality is contingent on prevailing institutional logics' (Fuenfschilling and Truffer, 2014: 774). Thus, institutional logics help to understand why actors behave in a certain way and how they perceive their interests (cf. Bosman et al., 2014). Two actors can perceive and act upon the same situation very differently due to the different institutional logics they operate under. We will show that a mismatch of institutional logics is an important feature of the transition towards integration of biomethane in the existing gas infrastructure. Moreover, in applying institutional logics we are able to show how existing infrastructure shapes actors' thinking and acting.

The aim of this paper is to characterize the institutional logics under which niches and regimes operate and analyze to what extent the difference in institutional logics can help explain why transitions are such slow processes. Furthermore, we investigate how the problem of mismatching institutional logics is addressed. Institutional theory offers the relevant concept of 'boundary spanners': actors that engage in strategies to connect different worlds (e.g. Zietsma and Lawrence, 2010: 194). We apply the institutional logics lens to how the niche of biomethane confronts the natural gas regime regarding the issue of biomethane injection and investigate boundary spanners' strategies aimed at creating productive working relationships. This leads to the following research question: How do the different institutional logics that guide gas network operators and biomethane producers influence biomethane injection into the Dutch natural gas grid, and how do boundary spanners intervene?

Several types of actors may supply biomethane, e.g. farmers, the waste sector, and large food production companies. In our case study we zoom in on the contact between farmers and network operators, because there the difference in institutional logics is most outspoken. So what happens when farmer Johnson meets the network operator? We will show the confrontation between the "hierarchy logic' that guides the network operator and the 'entrepreneur logic' that guides the farmers. We think that insight in this clash of logics will teach us about an essential issue in transition processes: the cumbersome interaction between parties coming from different backgrounds. Focusing on the underlying institutional logics brings us to the heart of the problem. It will create insight into whether these institutional logics are incompatible, and into how the institutional logics' mismatch may be addressed.

\section{Theory}

In this section we introduce the concept of institutional logics and describe different types of institutional logics. Then we elaborate on conflicting logics and on how the gap between different logics can be bridged.

Institutional logics is a relatively new and growing body of literature within institutional theory. It is similar to the concepts of logics of action (Bacharach et al., 1996), cognitive schema (Seo and Creed, 2002), and logics, forms, and practices (Sine and David, 2003). Institutional logics (in short: logics) are defined as 'the socially constructed, historical patterns of material practices, assumptions, values, beliefs, and rules by which individuals produce and reproduce their material subsistence, organize time and space, and provide meaning to their social reality' (Thornton and Ocasio, 1999: 804). In other words, the concept includes both practices (the typical way of operating) and the underlying belief system (ideas and guidelines) that influence individual actors' acting and thinking. This concept offers a comprehensive understanding of why and how actors behave the way they do. Furthermore, Thornton and Ocasio (2008) emphasize that institutions develop and change as a result of the interplay between their material and cultural foundations (p. 105). So while logics have a social dimension, they are also constrained by material artifacts.

Moreover, '... institutional logics determine what answers and solutions are available and appropriate in controlling economic and political activity in organizations' (Thornton and Ocasio, 1999: 806). However, while institutional logics condition actors' choices, '[actors] also have the capacity to innovate and thus transform institutional logics' (Thornton et al., 2012: 3).

In relation to transition processes, the logics concept enables us to observe more closely how niche and regime behaviors differ as well as what the underlying motivations for this behavior are. The concept includes both cultural and material aspects and acknowledges the duality of agency and structure. As such it is able to capture the complexity of transition phenomena. We believe it to be a suitable concept that will increase our understanding of why transition processes tend to be slow.

\subsection{Different types of logics}

Logics also enable us to characterize different types of organizations. Existing research on institutional logics focuses on the different institutional orders of society, i.e. family, religion, state, market, profession, and corporation (Thornton et al., 2012). Each of these orders is characterized by a set of 'ideal-type' institutional logics. In turn, organizations or sectors are shaped by field-level specific logics depending on their 
particular opportunities, restraints and resources. These specific logics are combinations of the ideal-type logics mentioned above (Thornton et al., 2012). The six institutional logics provide a yardstick to analyze and explain sector-specific logics. Here we will highlight the main goal and operating principles for the relevant ideal-type logics. The state aims to increase the community good and does so by bureaucratic mechanisms. Under the profession logic, people strive to increase personal reputation by relying on personal expertise and quality of craft. The family is geared towards increasing family honor by mechanisms of loyalty, household position, and patriarchal domination. The market logic dictates a focus on increasing profit through the mechanism of transaction. The corporation aims at increasing the size of the firm and operates according to the actors' status in the hierarchy. Finally, religion aims at increasing religious symbolism of natural events by using priesthood charisma and association with deities.

Despite differences in theoretical backgrounds, cultural theory shares with institutional logics the idea that a rational-choice perspective misses out on the social and cognitive aspects that influence what is perceived as rational. For example, in their highly influential book on cultural theory, Schwarz and Thompson (1990: 6-7) distinguish three ideal-type 'rationalities' related to three groups: the individualists, the hierarchists and the egalitarians.

In the individualists' market culture (similar to the market logic) people strive to exploit opportunities by engaging in market transactions. They focus on optimization of the end-product and on generating profit: they have a substantive rationality. In contrast, hierarchists operate according to orderly and fixed procedures (resembling the state and corporate logic). Following these procedures is more important than obtaining the most efficient outcome: they are guided by a procedural rationality. Moreover, since people are organized in orderly and ranked relationships there are differences in status. Finally, the egalitarians provide a critical rationality: they 'reject both the individualism of the market and the inequalities of the hierarchy' (p. 7). Instead they '[stress] the importance of fraternal and sororal cooperation, and therefore [strive] for social relationships that are voluntaristic and egalitarian' (p. 7).

When confronted with new developments, each rationality has a distinctive 'engineering aesthetic': its own definition of the 'good, the beautiful and the socially desirable' (Schwarz and Thompson, 1990: p. 11). Schwarz and Thompson (1990) argue that each actor is perfectly rational within its own rationality (p. 6). However, the different rationalities are not compatible with each other. This poses a challenge for (policy) debates, because the argumentations do not fit with one another. In terms of transitions, where different actors of the niche and the regime meet, we can see now why it is difficult to agree on a common problem definition, let alone select a solution.

\subsection{Conflict between logics}

While the logics that guide each organization or sector provide a (semi-)coherent package of practices and belief systems, two different sets of logics are not necessarily aligned (e.g. Thompson, 2013). Contradictions in logics between organizations 'form the bases of political conflicts' (Thornton and Ocasio, 1999: 805). Such a situation is called 'institutional contradiction': a misalignment of institutional logics creates pressure on the existing arrangements. Several studies show how organizations that used to work under logic A are pushed to work under logic B (e.g. Reay and Hinings, 2009; Thornton and Ocasio, 1999). In other words: 'Some of the most important struggles between groups, organizations, and classes are over the appropriate relationships between institutions and by which institutional logic different activities should be regulated' (Friedland and Alford, 1991: 256).

A specific form of institutional contradiction is 'structural overlap', in which 'individual roles and organizational structures and functions that were previously distinct are forced into association' (Thornton and Ocasio, 2008: 116). For instance, Reay and Hinings (2009) describe how health care professionals in Alberta, Canada had to move away from the dominant logic of 'medical professionalism' towards 'business-like health care'. Instead of the physicians using 'their professional knowledge to determine appropriate care for their patients', they now had to start working based on the principles of 'cost-effective treatment, lowest-cost provider and customer satisfaction' (p. 630). When niches need existing infrastructure, niche and regime actors are forced into association and structural overlap occurs.

\subsection{Boundary spanning}

When organizations with diverging logics are forced into association, how do they make things work (to some degree)? Institutional theory mentions the phenomenon of 'boundary spanning actors' that engage in 'strategies to manage cross-boundary connections' (Zietsma and Lawrence, 2010: 194). Traditionally, this research was geared towards science-practice cooperation and other forms of knowledge coproduction (e.g. Guston, 1999; Miller, 2001; Carr and Wilkinson, 2005; Tribbia and Moser, 2008). Here we apply this literature to a situation of structural overlap. By addressing the activities of boundary spanners we add to the research on agency in transitions (e.g. Markard et al., 2012; Farla et al., 2012; Smink et al., 2015; Wesseling et al., 2014, in press).

For the purpose of this research we focus on the micro-level of boundary spanning individuals and exclude the literature on systemic intermediaries (e.g. Van Lente et al., 2003; Klerkx and Leeuwis, 2008, 2009; Kivimaa, 2014). Boundary spanning individuals are found to be 'pivotal' in the management of inter-organizational relationships (Williams, 2002), especially in situations of 'no contact, disturbed or otherwise dysfunctional contact' (Klerkx et al., 2010: 398).

Boundary spanning strategies directed at actors operating under different logics may involve the establishment of boundary organizations (O'Mahony and Bechky, 2008). Boundary organizations "perform tasks that are useful to both sides and involve people from both communities in their work but play a distinctive role that would be difficult or impossible for organizations in either community to play" (O'Mahony and Bechky, 2008: 426). They 'stimulate collaboration by articulating how the organizations' interests diverge and by reinforcing their convergent interests' (Jolink and Niesten, 2012: 155) and thus, they 'help actors collaborate across different worlds' (O'Mahony and Bechky, 2008: 452).

Four essentials tasks that boundary organizations perform are presented by Tribbia and Moser (2008). In the first place, convening: organizing face-to-face contact between stakeholders to 'foster trust-building and mutual understanding' (p. 317). Secondly, translation of information and resources to assure that all communication is comprehensible for co-operating individuals and organizations. Thirdly, facilitating collaboration by bringing together co-operating groups for frank and transparent dialogue geared at establishing productive working relationships. Fourthly, mediation to ensure the fair representation of the various interests of stakeholders.

Boundary spanning is deemed successful if 'productive working relationships [have been created] despite divergent interests' (O'Mahony and Bechky, 2008: 455). Other authors define success in terms of increased mutual understanding (Franks, 2010: 286). O'Mahony and Bechky (2008) emphasize that not all conflicts will be resolved and that divergent interests will remain.

Furthermore, boundary spanning also happens within organizations and is labeled 'boundary shaking' (Balogun et al., 2005). Boundary shakers are change agents that implement 'change initiatives across internal organizational boundaries', mostly initiatives originating from the upper ranks of an organization. Boundary shaking practices involve: finding out the agendas and issues of others; convincing people of the merits of the initiative by framing the initiative to be fit with their agendas; stage management such as using experts to reinforce particular points; aligning measurement systems with the change initiative; and lobbying for help from more senior managers (Balogun et al., 
2005: 267). Kislov (2014) remarks that top-down boundary spanning may be less successful than initiatives emerging in a bottom-up fashion, given communities' resistance to external influence and control.

A prerequisite for boundary spanners is to be exposed to multiple or even contradictory logics, prompting reflection on these logics (Greenwood and Suddaby, 2006). Boundary spanners 'transpose ideas' (Greenwood and Suddaby, 2006: 38) and thus increase actors' 'awareness of alternatives' (Greenwood and Suddaby, 2006: 38, emphasis in original). Klerkx et al. (2010) found boundary spanners to be 'specific and dedicated actors', often being present in the function of consultant (p. 398). Common characteristics of boundary spanners are: good networking skills, effective interpersonal competencies, and ability to create trust (Williams, 2002).

Seen from the logics angle, skillful boundary spanners are an essential ingredient to enable the successful cooperation between previously unrelated organizations. This phenomenon is also recognized in transition studies: 'pragmatic system builders [are required] who make compromises and help translate some niche practices into forms amenable to actors in the regime' (Smith, 2007: 447). Such translation activities in a face-to-face setting provide 'stepping stones' between niche and regime. Other transition studies speak of 'intermediaries' (Elzen et al., 2012b) and 'hybrid actors' (Elzen et al., 2012a; Diaz et al., 2013; Kivisaari et al., 2013).

In this study we will identify the sector-specific logics guiding network operators and farmers; analyze how these different sets of logics 'meet' and whether some boundary spanners manage to close the gap.

\section{Method}

Fitting our aim to understand a complex social phenomenon we have conducted a case study. A case study design allows the phenomenon to be studied in its context (Yin, 2003). Our focus on institutional logics requires us to gain a comprehensive understanding of the functioning of biomethane producers and network operators in their context; something which other research methods offer to a lesser extent. Several data sources have been used. First, a database of over 250 news articles related to biomethane injection in the Netherlands during the period 2003-2012 served to identify the most important actors and activities that occurred in this period. In addition, relevant policy documents, annual reports, and research reports were analyzed to get an overview of (unsolved) technical and regulatory issues with regard to biomethane injection, and to prepare for the interviews. One researcher visited the 2011 and 2012 editions of the Energy Delta Convention in Groningen. This industry and science conference largely focuses on gas issues and provided insights into the current topics and culture of that sector.

Furthermore, 14 semi-structured interviews were conducted with relevant organizations in the field of biomethane injection. Interviewees were those people in the organization that worked closely on the issue of biomethane injection. Interviews were conducted with the national network operator ( 3 interviewees) and the three major regional network operators ( 4 interviewees). Five interviews were arranged with biomethane producers and boundary spanners. Since producers mostly hire a boundary spanner to organize part of the biomethane production, these boundary spanners could tell us most about the contact with the network operators. Due to this close connection between producers and boundary spanners we mention them as one group. We interviewed all boundary spanners that were identified in the news articles and within the network operators. Finally, interviews were conducted with two principal government representatives on the issues of biomethane injection and gas quality. These groups will be indicated in the results as 'Nat. network', 'Reg. network', 'Boundary spanner', and 'Government', respectively. Some interviewees have a double role, e.g. they work for the network operator as a boundary shaker. We indicate them as e.g. 'Reg. network/boundary shaker'.
The interviews took place between September 2012 and March 2013 and mostly lasted 1 to $2 \mathrm{~h}$ each. Interviewees were asked to describe how their organization dealt with the introduction of biomethane injection, what their motivations are to work on it, and what issues have to be solved (and how) to make biomethane injection successful. Interviews were fully transcribed and analyzed in NVivo to create a description of the different types of sector-specific institutional logics, and for examples of competing logics, as well as boundary spanning activities. We checked for intercoder reliability as a co-author also analyzed part of the interviews in NVivo. Interview quotes have been translated to English. We aimed to conscientiously convey the meaning and speech style of the interviewees, while staying as close to the original text as possible (Bryman, 2008: 454).

\section{Background on gas sector and biomethane}

The lion's share of Dutch gas comes from the large Groningen field, in the northern province of Groningen. The composition of Groningen gas is: $81 \%$ methane, $14 \%$ nitrogen, a small percentage of higher hydrocarbons, and finally some $\mathrm{CO}_{2}$. Compared to natural gas from other sources, it has a relatively low methane content and therefore is called 'low-calorific gas'. The calorific value of gas indicates how much energy one unit of gas contains. The calorific value is related to the Wobbe index: a measure to compare energy content for gases with different densities. Gas from so-called 'small fields' in the North Sea and on land as well as imported gas (e.g. from Russia) has a higher methane content and is therefore blended with nitrogen to match the composition of Groningen gas (Gas Transport Services, 2013: 17).

Biomethane is produced from biogas, which is the product of a codigestion process of manure and other organic materials (e.g. corn). By extracting $\mathrm{CO}_{2}$ from the biogas, the relative percentage of methane increases and the Wobbe index of natural gas is met (Platform Nieuw Gas, 2009). However, chemically, it does not have exactly the same composition. For instance, biomethane can contain some biological components related to the resources from which it is produced, which need to be filtered out (Platform Nieuw Gas, 2009). Fig. 1 shows the value chain of biomethane. It also indicates that injection is a necessary step to provide biomethane to the end user.

The organizational structure of the gas sector is as follows. The Groningen field serves as the starting point in terms of physical infrastructure as well as in legal terms. Natural gas is 'produced' by the NAM (Nederlandse Aardolie Maatschappij). It enters the network of the Gasunie, which transports the gas to the regional network operators. One can compare the gas network with the roads of a country. The highways transport large quantities of gas at high pressure $(80,67$, and 40 bar), whereas the regional and local grids transport smaller quantities at lower pressure (maximum 8 bar) (KEMA, 2010: 5-6). Gas traditionally flows only one way, from Groningen to the customer, and therefore supply and demand should be in balance at all times (KEMA, 2010: 7).

The Dutch Gas Law has been built on this arrangement and is therefore quite simple: it contains very little specifications about the gas quality (most notably the Wobbe index and the pressure; Government 1, 2012), because there used to be only one source (the Groningen field). Gasunie is responsible for the gas quality (which involves some blending and fine tuning), whereas regional network operators transport it to the customer. Gasunie is used to deal with large energy intensive industrial players that are directly connected to the 80 bar network (Schippers and Verbong, 2000: 215) and not with small parties. Conversely, regional network operators have more local contacts, but have limited knowledge about gas quality (other than Groningen gas). In this monopoly arrangement everything was relatively simple. "In case there were any questions, Gasunie was the answer" (Government 1, 2012).

The introduction of biomethane injection to the gas system represents a fundamental change. It means that the gas no longer flows 


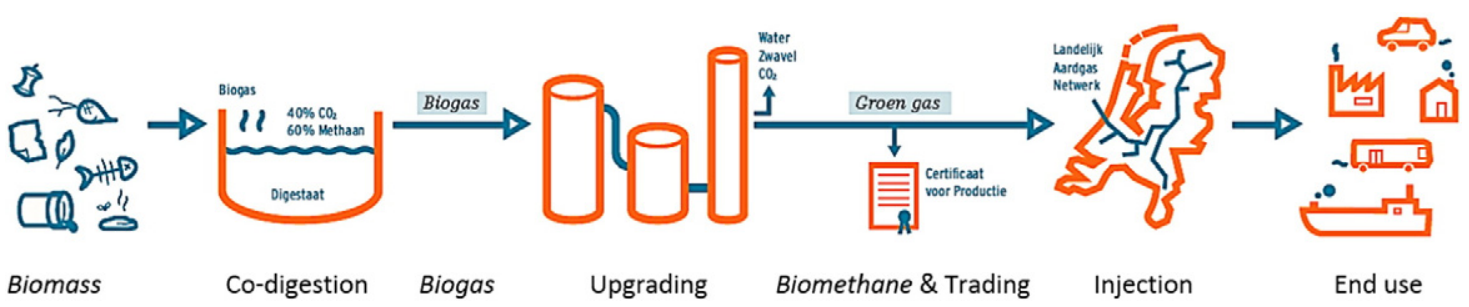

Fig. 1. Biomethane value chain (adapted from Nieuw Gas Krant, 2010: 4).

exclusively from upstream to downstream, but that gas can be added into the downstream 'nerves' of the system, and by new and different parties. This practice breaks the monopoly of Gasunie on supplying the Netherlands with gas. Moreover, it raises many technical, legal, administrative, and safety related questions. While the government pushes biomethane injection by allocating to it a large part of the renewable energy subsidy budget, no final regulation exists on a few essential issues (Platform Nieuw Gas, 2007: 22, 25; Boerderij Vandaag, 2009a; RVO, 2011). The biomethane projects that inject into the natural gas grid run on the basis of provisional regulation (ACM, 2009). Disagreement on final regulations covering these essential issues continues. Therefore, no new regulation has been introduced until at least July 2014 . In fact, only $13 \%$ of the proposed biomethane production capacity that was allocated subsidy in 2011 has been realized (RVO, 2014: 53), partly because of the problems related to cooperation with the network operators. The essential issues concern firstly, the gas quality and safety: what should be its calorific value (energy content) and what should be its composition to ensure flame stability in boilers and furnaces? Secondly, who is responsible in case of damage or accidents due to biomethane injection: the producer or the network operator? And finally, the Gas Law does not contain provisions that allow network operators to invest in infrastructure adjustments to facilitate biomethane injection. This is relevant, because farms are usually located near the most downstream part of the network, where gas consumption is relatively low. This limited injection capacity could be increased by connecting this particular network to a network with higher gas consumption, or by making adjustments to the network to enable the gas to flow upstream.

Two landscape changes influence the relation of network operators with biomethane. Firstly, due to the EU and Dutch liberalization agenda, in 2005 Gasunie was separated into a network operator (called Gasunie) and a sales company (called GasTerra) (Eerste Kamer der Staten-Generaal, 2012: 345). The same happened with the regional network operators in 2008-2009. As a consequence, network operators were in principle free to transport gas from any producer. This opened up new possibilities for other types of sources. This landscape change also affects the regime level as the liberalization program allowed network operators to set up a business development section that executes activities in the commercial domain. Such activities include the building of pipelines, upgrading gas, monitoring gas quality etc. The business approach of the business development unit now starts to cause friction with the regulated part of the network operator. As a result of these new incentives, pressure on the network operator to accept biomethane injection increased.

Secondly, societal concerns about the impact of gas on $\mathrm{CO}_{2}$ emissions as well as the eventual depletion of fossil resources force the network operators to consider more sustainable types of gases to maintain their 'license to operate'. For network operators to remain a viable business, it is essential that their network will continue to be used for gas transport. A related regime factor is that gas extraction from the Groningen field is expected to decline sharply in the next two decades (Gas Transport Services, 2013: 14-15). This supply needs to be substituted. Imports will increase, which means that gases with a different composition (high-calorific gas) will be transported (e.g. from
Russia). In the long run, the gas quality standard needs to be adapted (Ministry of Economic Affairs, 2012).

\section{Case description and analysis}

Firstly, we will describe the sector-specific institutional logics that guide the network operators and the producers, which we will summarize under the heading of 'hierarchy logic' and 'entrepreneur logic', respectively. These two logics will be compared to the ideal-type institutional logics as well as the three rationalities. Secondly, the mismatch of the institutional logics will be described in detail. Thirdly, we will show how various actors try to bridge the gap between the institutional logics. Quotes are used to show remarkable differences in logics.

\subsection{Institutional logics guiding network operators}

The most basic institutional logic influencing network operators is their operation according to the Gas Law and all its subsequent codes and norms. Since network operators are public entities, these documents prescribe whether they are allowed to undertake certain activities as well as how and with which type of materials they should do it. The codes and norms also need to safeguard non-discriminatory access to the network: all parties need to be treated uniformly. For new developments, prescriptions are often lacking and leave the network operator without guidelines about how to proceed. New developments either have to meet existing norms, or new norms have to be decided upon. In short, network operators are governed and constrained by a legal framework.

A network company is driven by codes and norms. So, very simple, if something is not mentioned in a norm, people don't know it.

[Regional network 1, 2013]

In terms of decision-making, network operators are organized hierarchically and formally. The hierarchy starts with the technician that checks the pipelines in a certain area, and runs via the administrative middle management layer, to end with the top management. Procedures tend to be extensive and relatively slow. Interactions with other parties have a formal character.

Secondly, network operators traditionally deal with large-scale arrangements, for infrastructure as well as administrative systems. They are tuned to work with large quantities of gas. Any change to the system is bound to come with (extremely) high overhead costs.

A connection to the national network has a fixed price of 300.000 euro. You actually have nothing then. You only have somebody making a hole in the pipeline where you can connect, but all the rest you need to do yourself. ... For this we are engineering for months to see what are the consequences for the transport network. All sums, plusses, minuses are made three times. Everything that happens needs to meet all standards.

[National network 1, 2012]

Network operators are also characterized by their preference for order and control. This is closely linked to their preference for large- 
scale operations. They like to keep both the infrastructure and the administrative system simple, they attempt to perfectly manage this system and tend to resist changes to it. A telling illustration is that network operators battle with each other for a yearly 'operational excellence' prize, awarded to the most smoothly and efficiently operating organization.

Thirdly, for network operators, it is of utmost importance that the gas supply meets the highest standards for safety and reliability. For instance, occurrences of odorless gas or incorrectly burning flames are unacceptable for them, due to the risk of explosions. This concern partially stems from the network operators' responsibility for the gas quality. From the preoccupation with safety and reliability follows a strong tendency of risk-averse behavior. Network operators prefer to know and cover all possible risks of new activities before getting started.

Finally, network operators are pledged to make decisions that are optimal from a societal perspective. Given that their costs will be divided over energy users, network operators need to consider whether activities are efficient from a societal point of view.

These elements of the sector-specific logics under which network operators function are a combination of the ideal-type state logic and profession logic as characterized by Thornton et al. (2012). Network operators are influenced by state logic because they are state-owned. This results in a high degree of regulation and bureaucratic decisionmaking, and a prescribed focus on the increase of the community good (e.g. optimal and safe supply of gas for all). Moreover, network operators also draw on the profession logic, which shows in the high value that is being placed on expertise and quality of craft in managing the gas infrastructure.

We also recognize the profile of a hierarchist as described by Schwarz and Thompson (1990). Network operators operate on the basis of 'orderly and ranked relationships' (p. 6) and follow a 'procedural rationality' (p. 7), meaning that the procedure is the guiding principle rather than the outcome. Moreover, the preference for large-scale and centralized arrangements matches the typical 'engineering aesthetic' (p. 11) of the hierarchist. We summarize the sector-specific logics under which the network operators function under the heading of 'hierarchy logic'.

\subsection{Institutional logics guiding biomethane producers}

The institutional logics biomethane producers operate under are quite different from the hierarchy logic related to the network operators. First of all, for farmers, biomethane production is a supplement to their core business: their hearts really are with their cows and crops. Secondly, producers are private organizations and therefore only invest in a project if they expect it to be profitable. This is an essential condition for their involvement. They strive for efficiency and therefore share an interest in making optimal use of their resources. They try to create value from the waste streams they have. For farmers, biomethane production is a piece in a larger puzzle of closing nutrient cycles. By digesting manure they reduce surplus manure (which is expensive to get rid of) and turn it into a valuable product that can be used as fertilizer.

And for these farmers, it is not about the gas, it is about the minerals. From that moment on we have always emphasized it is about the link between minerals and gas.

[Boundary spanner 1, 2012]

Third, the farmers and the related boundary spanners are focused on regional development. They believe their activities can be a stimulus for the local economy.

A simple example: we are now busy to think of a new green economy for regions in decline, because that's where you want a new economy.

[Boundary spanner 1, 2012]
Fourth, producers wish to contribute to the production of renewable energy and more generally, sustainability. They are intrinsically motivated.

Certainly, it was an economic opportunity, but if it hadn't been for sustainability, we wouldn't have taken the initiative. So sustainability was our priority, that was absolutely clear, reasoned purely from the heart.

[Boundary spanner 2, 2012]

Finally, the operating style of producers is to decide quickly and act pragmatically. For instance, they do not participate in biomethane related organizations or platforms unless they all pursue the same concrete goals.

In sum, producers are influenced by both the market and family logic as described by Thornton et al. (2012). Increasing efficiency and thereby profits is one of the main concerns of farmers, fitting the commercial market logic. Elements of the family logic are visible in pragmatic, family-based decision-making (see also Section 5.3.1) and an extension of the family loyalty to their region. Farmers also have much in common with the individualists' market rationality as depicted by Schwarz and Thompson (1990). Their main concerns are the results on the ground; procedures are only the means to that end. Moreover, the producers share some of the egalitarian logic too: it shows in their emphasis on contributing to the local community and their more small-scale and regional engineering aesthetic. We summarize the sector-specific logics that guide the biomethane producers under the new heading of 'entrepreneur logic'.

\subsection{Institutional logics mismatch}

From 2008 onwards, a large subsidy creates a boost in the number of biomethane projects and, as a consequence, network operators are confronted with requests for injection of this gas into their grid. This is an example of 'structural overlap': previously unrelated organizations are forced into association (Thornton and Ocasio, 2008). Below we describe how the mismatch of logics unfolds in practice for three clusters of competing logics: hierarchical vs. pragmatic decisionmaking; large-scale vs. small-scale arrangements; and safety vs. efficiency focus.

\subsubsection{Hierarchical vs. pragmatic decision-making}

A first clash of logics happens between the operation of network operators according to codes and norms on the one hand, and the quick and pragmatic operating style of the producers on the other. Network operators have to explain to producers the rules that govern the gas sector.

Welcome to this world, you are now a gas producer. That also means you now need to have an emergency service, you need to properly settle payments, monitor quality, have a standby service for Sunday morning $4 \mathrm{am}$. Somebody needs to sit there who can take action.

[Nat. network 2, 2012]

From the network operators' first reactions to biomethane injection, it shows that the current system is taken as a given. This means that any new development should meet the standards of this current system.

Biomethane needs to be equal to grey gas. So in the beginning, colleagues wanted to demand that biomethane could only contain those elements that are present in natural gas.

[Reg. network/boundary shaker 1, 2013]

Initially, employees of network operators respond to the idea of biomethane injection by pointing out all the possible problems it could create. 
An enormous mountain of objections emerged, of why we shouldn't get involved in all of this.

[Reg. network/boundary shaker 1, 2013]

This rather conservative way of reasoning leads to statements such as: "it is not possible"; "it is not allowed"; "we have always done it this way"; "we do not do things that way"; and "I do not have personnel for that" (Reg. network/boundary shaker 1, 2013). Moreover, new opportunities are at first not taken seriously. Employees expected the interest in biomethane injection to "go away" (Reg. network/boundary shaker 1, 2013). At the national network operator it was practice for a long time to "hold off biomethane injection". People were afraid biomethane would corrode the pipelines (Nat. network 2, 2012).

There was a time that when you said we were going to inject biomethane, you would pretty much be shot here in the hallway. "We don't want this; it is dangerous for our network."

[Nat. network 2, 2012]

Once a number of biomethane injection projects were running on the basis of provisional regulation (ACM, 2009), network operators turned to create protocols and guidelines to standardize this new development. Biomethane had to be completely integrated into the current system and should be treated as any other 'commodity'. As indicated in the Background on gas sector and biomethane section, this does not mean that from the farmer's perspective all problems have been solved. The integration of biomethane into the network operators' system could be seen as a form of the 'centralized direction' that characterizes the hierarchist's profile.

In accordance with the policy of Netbeheer Nederland [branche organization of Dutch network operators] we formulated the criteria in such a way that in terms of calorific value and safety, biomethane is no more or less than natural gas. In this way, our people on the ground can just do their job with standard decisions and standard safety equipment, they will not notice anything.

[Reg. network/boundary shaker 2, 2013]

However, the formal decision making style of network operators is at odds with the informal way of operating of producers. The large cultural difference really hampers progress on the projects, because it creates distrust among the parties. A farmer usually uses his family capital to set up his activities and therefore needs to trust his partners before he will invest.

I am at the kitchen table and try to get a taste for what are the issues. At a certain moment, the wife comes in with coffee and the agrarian says "come sit here with us". Then you know this is a very important moment, because he is putting his private money into this initiative. I have learned this is a very important moment, because somebody talking on behalf of a large company, talks about the company's money. But a small entrepreneur speaks about his own money. So, if Mother doesn't want it, it won't happen.

[Reg. network/boundary shaker 1, 2013]

If the network operators, those energy guys visit the farmer, they arrive with three big lease cars on the property, all three in grey suits. No way the farmer will do business with them. He really doesn't feel like it.

[Boundary spanner 2, 2012]

Both parties' decision-making systems show a mismatch too. Producers like quick decisions on the basis of concrete numbers. However, network operators have extensive structures and protocols to follow, before taking a decision. So producers complain about the complicated and slow, or even ineffective way of decision-making.
They were all enthusiastic and next we got a bedlam ${ }^{1}$ and then it wasn't fun anymore. Network operators are really strong in this; whenever you make an appointment with one person, you will get six of them.

[Boundary spanner 2, 2012]

For example, [reaching agreement about] contracts and prices with energy companies takes months. Whereas for a farmer it is like "shall we do this, yes or no?"

[Boundary spanner 2, 2012]

In contrast, this is how a network operator describes their procedures:

We have an account manager who takes care of client contact and the offer trajectory. And we have a technical team. Every once in a while I discuss the progress with them. Next to that there is a judicial specialist to monitor especially the legal side of the issue. Furthermore, the technical people are also in a national group to help establish coordination in the sector. Also Netbeheer Nederland [branche organization for Dutch network operators] engages in coordination on this issue.

[Reg. network 3, 2012]

Meanwhile, network operators prefer to work with a professional organization, instead of a farmer whose core business is not biomethane production.

I find the agricultural sector more difficult and more challenging. For example, in the waste sector organizations have a business development department with a manager. And the manager will come by some time, ask for an offer, you discuss what you are going to do, and what you are not going to do, everybody organizes their own thing. But these small entrepreneurs, for them it is much more difficult to deliver. They are not so organized, or they are organized, but well, during the day he is working with his cows. So you need to help them a bit more, they need more attention.

[Reg. network/boundary shaker 1, 2013]

To improve the interaction, network operators appoint someone as "account manager" (Reg. network 3, 2012). This person is meant to specialize in biomethane projects so that the network operator can learn faster. Moreover, biomethane producers should now have a clear contact point. This response is in line with the hierarchy logic: the account manager has a formal position matching the hierarchical decisionmaking structure. This is an example of how logics determine the type of answers and solutions that are perceived by the actors (cf. March \& Olsen 1976 quoted by Thornton and Ocasio, 1999: 806). However, this approach is not likely to provide a solution for the culture differences and trust issues with biomethane producers, who are used to work in an informal way.

\subsubsection{Large-scale vs. small-scale arrangements}

Network operators are used to dealing with large scale infrastructure and large quantities of gas. Biomethane projects produce relatively small amounts of gas. This is where a lot of resistance to biomethane injection comes from: "It is much work for very little quantities with potentially many risks" (Nat. network 3, 2012). This is especially true for the national network operator. The focus on large scale operations precludes fitting in biomethane projects easily and efficiently.

\footnotetext{
1 In Dutch: Poolse landdag.
} 
When we step into this type of projects, it just gets too expensive. Whenever we make something according to our standards, it is always meant to be very large, very big quantities, and meant to last for a very long time.

[Nat. network 1, 2012]

We had a discussion with the NAM. The idea was to use their pipelines of the small fields for biogas. Can't we transport biogas through those pipelines? "What are you talking about concretely?" Well, about 30 million cubic meters. Answer of the NAM: "Per day?" No, per year. Just to indicate the difference in order of magnitude. That is also what we see with these farmers.

[Nat. network 1, 2012]

Moreover, the administrative systems of the network operators are also extensive, especially for the three large regional network operators. Incorporating the physical changes of the gas flow into these systems is another hurdle for biomethane injection.

Same for billing. It sounds simple, gas is being injected and somebody buys it. Easy peasy. Just add and deduct. But when you speak about systems with 3 million clients, such a change is not only very expensive, but also very vulnerable for mistakes. You have to do it right for all your clients at once. That is not so easily done. It is a disadvantage of large companies. You cannot forget anything. So the colleagues who deal with this, these changes caused them quite some stomach aches.

[Reg. network/boundary shaker 1, 2013]

This section shows how the large-scale infrastructure and its accompanying practices influence people's ideas about what is possible or not. The physical infrastructure of the gas sector determines to a large extent the scope of the logics under which network operators function. But apart from the physical possibilities, this section also displays a dislike for small projects and diversity, and conversely, an attachment to large-scale systems. We see here how the material and cultural aspects of the logics are interrelated.

Biomethane projects not only produce relatively small quantities of gas, they are also dispersed geographically. Furthermore, most projects feed into the smallest, local grid. For network operators, this means that their carefully streamlined physical and administrative systems are disturbed. Gas used to flow from the Groningen field all the way down to the customer. Biomethane breaks the monopoly of Gasunie by injecting at the downstream level and by introducing new producers to the system. As a consequence, the traditional gas transporter (Gasunie) no longer wants to be responsible for the gas quality.

Gasunie's sole responsibility for the gas quality could no longer be maintained. Because Gasunie says "well, if farmer Johnson is going to mess around, we are no longer responsible. You know, gas is a craft".

[Reg. network/shaker 1, 2013]

If all biomethane could be injected upstream in the gas grid, there would be no problem. This is what happens with the natural gas from small fields, that also has a different composition than the Groningen gas. It is really the local element that clashes with the current large scale and one-way character of the system. This is another example of how logics determine the type of answers and solutions that are perceived by the actors (cf. March \& Olsen 1976 quoted by Thornton and Ocasio, 1999: 806).

I think the big difference is that [small fields] happen upstream, so at the beginning of our network. Then it doesn't matter so much, because you put everything together, it mixes partially and then finally it passes our treatment facilities. ... So that is completely part of our network. And it is also very manageable, those small fields. Whereas [biomethane] happens somewhere in a back alley, so to speak.

[Nat. network 3, 2012]

If all biomethane producers would just upgrade the gas and would hand it over at 67 bar in Ommen [upstream point in the grid], there would be no problem whatsoever.

[Nat. network 2, 2012]

Given their preference for order and control, it seems they resist changes that make their system more complicated. This is true for both the number of grid connections and the (natural) variability of biomethane.

Then you also get statements here like "we don't want to make a porcupine of our network". In other words, our gas network only has a limited number of connections. And if we have to make a connection for everyone that wants to inject in or draw from [the network], that requires a totally different way of managing the gas network.

[Nat. network 1, 2012]

Biomethane projects also require the planners of the gas flow to think differently. Whereas their biggest challenge used to be ensuring maximum gas supply on a cold winter day due to very high gas demand for household heating (avoiding a shortage), they now have to ensure that the grid does not blow up on a hot summer night (avoiding a surplus) due to too much biomethane injection in combination with too little demand.

This section shows that apart from infrastructural and economic limitations for biomethane injection, the hierarchy logic feeds network operators' resistance. In line with the bureaucratic decision making (Thornton et al., 2012) or procedural rationality (Schwarz and Thompson, 1990), they seem to dislike new things, having to change their ways, and to disturb the current order or streamlined system. The hierarchy logic naturally slows down new developments.

\subsubsection{Safety vs. efficiency focus}

One of the most important goals for network operators is to guarantee the safety and reliability of the grid. Biomethane is perceived as a threat to these principles. The national network operator seems most concerned about the integrity of the grid, i.e. the prevention of damage to their infrastructure (Gasunie, 2006; Leeuwarder Courant, 2007), whereas the regional network operator seems to be most concerned about the safety of customers.

Network operators sometimes state very boldly, "well, my CEO says: rather go to court 10 times than one dead body".

[Government 2, 2012]

In order to facilitate biomethane projects, the network operators came up with provisional regulation (ACM, 2009) based on knowledge available at that point. The criteria in this regulation are rather strict, so as to be 'on the safe side'. These are the criteria that the current projects operate under. In the meantime, the network operators continued to research and fine tune this list of criteria. Some parameters will be relaxed, whereas others are likely to be narrowed down. Also the current projects will have to meet this new set of criteria. This fine tuning is an annoyance to the producers, who object to this moving target.

We decided to play it safe. We demand sterilization of the gas and also a biological filter. Now we are busy checking a number of these filters to see how much bacteria they catch and whether all this is necessary or whether we could be a little bit more relaxed about it.

[Nat. network 3, 2012] 
Interesting to observe is that for 'safety' no objective measure or threshold exists. This makes it a very difficult concept for negotiation. However, it is a central concept in this case.

Moreover, producers and network operators disagree on who is responsible for the gas quality at the customer (called 'exit specs'). Network operators want entry specs for biomethane to be equal to the exit specs the customer is used to. Producers think it is the responsibility of the network operator to balance potential differences between entry and exit specs. Moreover, they also explain that gas flows blend and therefore entry specs can be broader than exit specs. Here we see very clearly the mismatch between operation according to codes and norms and applying the strictest criteria versus a type of pragmatic reasoning aiming to secure efficient operations. As Friedland and Alford (1991) wrote, it is a struggle over 'by which institutional logic different activities should be regulated' (p. 256).

A very simple example. The gas from my installation has a temperature of 30 degrees. That is easy, because like this I don't have to cool it down. Then I put it in the network, which is under the ground, and 100 meters later the gas is no longer 30 degrees but 5 degrees. The norm at the customer is, [the temperature] has to be below 20 degrees. So I say, "I can easily inject the gas at 30 degrees, because 100 meter later it has already cooled down". What does the network operator say? "No, not allowed, 20 degrees".

[Boundary spanner 2, 2012]

In the end the injection requirements needs to be such that the gas can be transported directly to the people who use it.

[Nat. network 2, 2012, emphasis added]

Finally, network operators have difficulties trusting the measurements that farmers share with them (Boerderij Vandaag, 2009b). They are very much aware of the different goals they each pursue and fear that the profit driven producer will jeopardize their own dedication to safety and reliability.

What is difficult is that the whole surveillance mechanism is with the producer and that we need to trust the blue eyes of the producers that all is well and that he works neatly according to the rules. Well, this is quite hard, especially when the producer has a strong financial drive.

[Reg. network/boundary shaker 2, 2013]

\subsection{Boundary spanning}

Despite the incompatible logics, the pressures to make biomethane injection work are still present, e.g. in the form of a 1 billion euro subsidy grant. We observed that both boundary spanning and boundary shaking activities are employed to create productive working relationships between producers and network operators. We first discuss boundary spanning activities between the different logics and then proceed with boundary shaking activities within the network operators.

\subsubsection{Boundary spanning between producers and network operators}

We found two different types of boundary spanners. Both boundary spanning initiatives originate within consultancy firms and are led by a consultant. This role of consultants was also observed by Klerkx et al. (2010). We first discuss boundary spanner 1, whose activities include convening, translation, and facilitating collaboration (cf. Tribbia and Moser, 2008). Boundary spanner 1 engages in convening and describes what happened when the farmers and network operators first met each other:
The first thing I did, [...] I will never forget. On the right were all the people of the network and energy companies and on the left were the farmers. I could have done my complete presentation naked ${ }^{2}$ : they totally didn't see me. They thought, "well, those are the men that have to produce the biogas. Well, and if they don't produce, we don't have a business case. So we need to trust them that they will produce and do it right". And the farmers thought, [...] "well, they need to pay us, otherwise we have a problem". [...] It was not distrust, but they both have such a different focus, such a different core business. And with such a focus it is difficult to sympathize with somebody else's core business and focus.

[Boundary spanner 1, 2012]

Due to the differences between the two parties, the next activity of boundary spanner 1 is to literally translate the communication.

We were hired to keep everybody together, [...] because an energy man can speak the same language as a farmer, but they don't always understand each other.

[Boundary spanner 1, 2012]

In some cases, literally being the translator, really. The farmer talks to me and I translate it into energy language for the energy company, and the other way around. In most cases I was the person overseeing the letters and the communication of the energy company to the farmer. And during conversations, when the energy company worked with abbreviations like specs and Wobbe, then I would translate like "they are talking about this and that".

[Boundary spanner 1, 2012]

Finally, boundary spanner 1 aims at achieving productive working relationships by facilitating collaboration. Each organization should stick to their trade and when cooperating, these organizations should openly share information and make sure they constantly communicate.

It is also a matter of every man sticking to his trade. A dairy farmer is not a gas guy. That's a very big difference there. And a gas guy is not a dairy farmer, you shouldn't have him hug a cow. It won't work out, so stick to your trade and involve the others.

[Boundary spanner 1, 2012]

Boundary spanner 2 has a different approach, including the creation of a boundary organization as well as engaging in translation and mediation activities. From the start, boundary spanner 2 intended the boundary organization to be a bridge between the large-scale arrangements that characterize the energy sector on the one hand and small scale energy projects on the other. Moreover, according to boundary spanner 2 this organization should have a commercial basis, given that it operates between commercial parties. The boundary organization buys biogas from its producer (the farmer) and takes care of the upgrading process. It then sells the resulting biomethane of multiple farmers to the energy company. Thus, boundary spanner 2 aims to remedy the hierarchical vs. pragmatic decision-making gap and the large-scale vs. small-scale gap.

The core of our business plan is that we start a company which will fill the void between biomass and the big energy world; a link between the small scale and the large scale. And moreover, it needed to be a commercial firm. Energy is a commercial world, so you shouldn't put something like the State in between the biomass business and the energy business.

[Boundary spanner 2, 2012]

\footnotetext{
2 Original quote: in m'n blote kont.
} 
So whereas boundary spanner 1 aims to bring the various parties together and attempts to ensure a smooth process, boundary spanner 2 circumvents direct interaction between farmers and network operators. The new boundary organization stands between the two parties and the boundary spanner contacts each side separately. Farmers and network operators no longer meet each other in person.

The translation activities that boundary spanner 2 engages in go beyond the literal translation mentioned above. The boundary spanner adapts to each actors' way of doing business, taking on a different attitude and outfit for every actor. This includes very down-to-earth things such as matching clothing style and car brand as well as knowing how the farmer makes his calculations. These activities are underpinned by a thorough understanding of the different socio-cultural part of the logics.

What I enjoy very much, when I go to our customer, to our farmers, then I look like this [comfortable pullover]. When I go talk with the network operator, I get my grey suit out from the closet.

[Boundary spanner 2, 2012]

I have a space wagon, a Chrysler Voyager, and that is a big car, but luckily a bit indefinable for people, it is not a Mercedes. I have experienced a farmer passing by my car, looking, and saying "Chrysler". And I had seen his car and said "Mercedes". That was all we needed to say about this topic. Just those two words. Energy firms don't have this understanding of the agricultural sector. You need to be willing to connect these two worlds. You need to be able to turn the switch: now I am like this and now I am like that.

[Boundary spanner 2, 2012]

Boundary spanner 2 also aims to achieve productive working relationships through mediation. By presenting the network operators with the entrepreneur logic guiding the producers, the network operators are challenged to reconsider their practices or at least to provide arguments for these practices.

In terms of success, both boundary spanners increase the amount of mutual understanding. At the same time, this seems to be a more important aim for boundary spanner 1 than for boundary spanner 2 . Because it is not expected to solve the logics conflict once and for all (cf. O'Mahony and Bechky, 2008), both boundary spanners more realistically aim for a productive working relationship. Both types of boundary spanning seem to have created such a relationship. However, various contentious issues remain.

The interview quotes above show that in-depth knowledge of the two parties' institutional logics and strong interpersonal competencies is required for successful boundary spanning. These enable the boundary spanners to translate, facilitate collaboration, and mediate between the different logics.

\subsubsection{Boundary shaking within the network operator}

We also found boundary spanning activities within the network operators' organizations, resulting from the ambition of their topmanagement to integrate biomethane into the grid. Both network operators employed professional change managers with experience in the energy sector to address the issue of biomethane injection. While network operators present a very male-dominated technical environment, in both cases the change managers were women. For two network operators it proved crucial to work closely with their technicians on the ground to make the implementation of biomethane injection successful. Whereas one boundary shaker started by interviewing all kinds of people in the organization to gather a bottom-up view of all issues to be tackled, the other boundary shaker's innovation department designed top-down instructions for their employees. The latter boundary shaker eventually had to take a more bottom-up approach too, to guarantee a successful incorporation of biomethane injection into the organization. This is in accordance with Kislov's (2014) remark that top-down boundary spanning may be less successful than bottom-up initiatives.

The bottom-up project dealt with finding out the technicians' agendas and issues (Balogun et al., 2005).

I really sat down next to people to see how things are being done. And ask: how do you do that, how does it work, why can't we do it this way? It was not sufficient to ask: hey, organize that for me. I went to get coca cola many times. I really visited these people, sat next to them. Until the point they would do what I asked of them.

[Reg. network/boundary shaker 1, 2013]

The next step involved convincing people that the change initiative was not in contradiction with their agendas, but could be accomplished within the set of limitations they faced. Therefore, the boundary shaker helps people to become aware of alternative options (Greenwood and Suddaby, 2006).

People say: I don't have personnel for that, or I first need to organize time for that. And then I say: well, then you hire people. That is something people often don't think about.

[Reg. network/boundary shaker 1, 2013]

Getting everybody along and moving towards pragmatic thinking instead of just mentioning all the risks and trying to cover them all. But really consider, which risks do we really face, what is the probability of that effect and which risks do we then need to tackle?

[Reg. network/boundary shaker 2, 2013]

The help of a senior expert was required to convince people of the change initiative. It must be someone who believes in the new development and will convey the story to the employees. This is an example of stage management (Balogun et al., 2005).

The boundary shakers presented above show all important characteristics of boundary spanners: good networking skills, effective interpersonal competencies, and ability to create trust (Williams, 2002). The creation of trust might be the crucial element in this case, as the following quote demonstrates.

I think it works when you emphasize the soft side, I think that is the key. If people don't feel like it, they won't do it; when people feel trust, they will do it. That's why I put a lot of attention to this soft side. I mean, anybody can find numbers.

[Reg. network/boundary shaker 1, 2013]

In sum, we have observed different types of attempts at bringing the different sectors and logics together. Our observations show that the logics that people operate under have some latent flexibility and that people can become enthusiastic about new initiatives. However, a convergence of logics is unlikely to occur and the result of the boundary spanning will be partial truces and settlements. Still, these results go beyond what can be achieved by just bringing people together and exchanging 'factual' information. Therefore, 'pragmatic system builders' may indeed be necessary to create 'stepping stones' between niche and regime (Smith, 2007) to skillfully address conflicting logics. Transitions may require people to get in touch with other logics, change their mind and practices, and so open up new avenues for change.

\section{Conclusion}

This study shows that mismatching institutional logics between gas network operators and biomethane producers complicate the integration of biomethane into the grid. Whereas network operators function under a hierarchy logic, biomethane producers operate under a 
divergent entrepreneur logic. Forced into association through a renewable energy subsidy, difficulties arise when the two parties get into direct contact. So when farmer Johnson meets the network operator, friction occurs regarding the goals pursued, decision-making style, and the scale of operations. These frictions slow down biomethane injection projects. Moreover, the frictions contribute to the fact that a very large part of the allocated subsidy is not spent, because many biomethane projects have not been realized.

We observed that boundary spanners address this situation of mismatching logics. With their activities they help to bridge the gap between logics. Essential elements of their strategy are convening, translating, facilitating collaboration, and mediation. In one case this involved the creation of a boundary organization. While increased mutual understanding between biomethane producers and network operators is part of the result, this does not automatically lead to productive working relationships. The logics mismatch will probably never be solved completely.

Moreover, we found 'boundary shaking' occurs within the organization of the network operator. This involves finding out employees' agendas and issues, convincing the employees of the change initiative, and using stage management strategies. Here, the creation of trust is a crucial element. Both boundary spanners and boundary shakers are people that have a thorough understanding of the logics guiding all parties involved and that employ effective interpersonal competencies.

\subsection{Contribution to the sustainability transitions field}

With this research we address the question what niche-regime interaction looks like. For this purpose we used the institutional logics approach, which proved a valuable approach to study the confrontation of niche and regime actors. This approach is different from most other studies that have taken a more meso-perspective. Putting on a logics lens enhances our understanding of why transition processes tend to be slow. The existing logics influencing the different actors may leave very little room for the change that is necessary for a transition, given the embeddedness and stability of logics in both thinking and acting. The institutional logics approach is particularly useful to study how physical infrastructure shapes actors' thinking and acting, and vice versa. The dynamics of logics over time and the factors that contribute to convergence or divergence are a topic for future research. Moreover, research with a longer timeframe can investigate to what extent the changes in the regime are temporary or are being institutionalized (Fuenfschilling and Truffer, 2014).

Our analysis of boundary spanning activities adds to insights into agency in transition processes, a prominent topic in the sustainability transitions field (e.g. Farla et al., 2012). Boundary spanning activities are one way in which individuals can purposefully contribute to change processes. The boundary spanning activities we identified play a central role in the contact between niche and regime. Boundary spanning may encourage the opening up of the regime to novelty. The case shows that when different sectors are forced into association, boundary spanning happens at multiple points in the socio-technical system. The subsidy that causes the structural overlap sets in motion a 'ripple effect': it creates frictions both between sectors with different logics and within organizations. For each of these ripples dedicated boundary spanning or shaking activities are necessary. Future research can identify fruitful strategies to create productive working relationships between new and old actors as well as institutional change. More research into boundary spanners' activities, skills, and challenges will increase practitioners' ability to create and exploit transition opportunities.

This study also shows the crucial role of infrastructure in the energy transition. Previous research has called for more attention to the role of infrastructure in the development of new technologies (Loorbach et al., 2010). This paper shows that the gas network operator functions as a 'gate keeper' (Lieberherr and Truffer, 2015) and therefore is an actor that merits more attention. The case discussed here adds insights into the functioning and challenges of the gas sector when it comes to integrating renewable energy technology (see also Goldthau, 2014).

\subsection{Policy recommendations}

In the case discussed in this paper, we perceive a clear mismatch between the subsidy policy and the socio-technical system. The subsidy sets in motion various biomethane projects, but due to the characteristics of the gas network a substantial part of the subsidy will not result in increased biomethane production. Therefore we claim that to increase renewable energy production, policies should not only be aimed at the new technology. Additional policies should be directed at the existing regime actors that need to accommodate the new technology. This asks for dedicated policies and for this a comprehensive understanding of the sector at hand is necessary. However, while a dedicated regulatory framework that stimulates the integration of biomethane into the grid will facilitate niche-regime interaction, it will not erase all logics mismatches. To deal with these issues, boundary spanners are essential. Therefore we expect a large demand for skilled actors and smart boundary spanning strategies to forge productive working relationships during the phase that renewable energy technologies are scaling-up and are confronting regime actors.

\section{Acknowledgments}

We are grateful for constructive comments by the reviewers and by Dr. Neil Thompson and Lea Fuenfschilling on earlier versions of this paper. We would like to thank the Netherlands Organisation for Scientific Research (NWO) for financial support in the framework of the Energy Transitions program [grant number 434-09-242].

\section{References}

ACM, 2009. Aanvullende voorwaarden RNB Groen Gas Invoeders. Available at, https:// www.enexis.nl/Documents/algemene-voorwaarden/enexis-voorlopige-aanvullendevoorwaarden-rnb-groen-gas-invoeders.pdf2009 (Last accessed: September 23, 2013).

Arapostathis, S., Carlsson-Hyslop, A., Pearson, P.J.G., Thornton, J., Gradillas, M., Laczay, S., Wallis, S., 2013. Governing transitions: cases and insights from two periods in the history of the UK gas industry. Energy Policy 52, 25-44.

Arapostathis, S., Pearson, P.J.G., Foxon, T.J., 2014. UK natural gas system integration in the making, 1960-2010: complexity, transitional uncertainties and uncertain transitions. Environ. Innov. Soc. Transit. 11, 87-102.

Bacharach, S.B., Bamberger, P. Sonnenstuhl, W.J., 1996. The organizational transformation process: the micropolitics of dissonance reduction and the alignment of logics of action. Adm. Sci. Q. 41 (3), 477-506.

Balogun, J., Gleadle, P., Hailey, V.H., Willmott, H., 2005. Managing change across boundaries: boundary-shaking practices. Br. J. Manag 16 (4), 261-278.

Bosman, R., Loorbach, D., Frantzeskaki, N., Pistorius, T., 2014. Discursive regime dynamics in the Dutch energy transition. J. Environ. Innov. Soc. Transit. 13, 45-59.

Boundary spanner 1, 2012. Interview Conducted in Person on October 5, 2012.

Boundary spanner 2, 2012. Interview Conducted in Person on October 16, 2012.

Bryman, A., 2008. Social Research Methods. Oxford University Press, Oxford; New York.

Carr, A., Wilkinson, R., 2005. Beyond participation: boundary organizations as a new space for farmers and scientists to interact. Soc. Nat. Resour. 18 (3), 255-265.

Courant, Leeuwarder, 2007. Gasunie zet rem op groen gas om risico's, November 21, no page number.

Diaz, M., Darnhofer, I., Darrot, C., Beuret, J.-E., 2013. Green tides in Brittany: what can we learn about niche-regime interactions? Environ. Innov. Soc. Transit. 8, 62-75.

Eerste Kamer der Staten-Generaal, 2012. Verbinding verbroken? Onderzoek naar de parlementaire besluitvorming over de privatisering en verzelfstandiging van overheidsdiensten. Deelrapport. Available at, http://www.eerstekamer.nl/ behandeling/20121030/deelrapport_van_de_parlementaire/f=/vj4117chfdzq. pdf (Last accessed: September 23, 2013).

Elzen, B., van Mierlo, B., Leeuwis, C., 2012a. Anchoring of innovations: assessing Dutch efforts to harvest energy from glasshouses. Environ. Innov. Soc. Transit. 5, 1-18.

Elzen, B., Barbier, M., Cerf, M., Grin, J., 2012b. Stimulating transitions towards sustainable farming systems. In: Darnhofer, L., Gibbon, D., Dedieu, B. (Eds.), Farming Systems Research Into the 21st Century: The New Dynamic. Springer, Dordrecht, pp. 431-455.

Farla, J., Markard, J., Raven, R., Coenen, L., 2012. Sustainability transitions in the making: a closer look at actors, strategies and resources. Technol. Forecast. Soc. Chang. 79 (6), 991-998.

Franks, J., 2010. Boundary organizations for sustainable land management: the example of Dutch environmental co-operatives. Ecol. Econ. 70 (2), 283-295. 
Friedland, R., Alford, R.R., 1991. Bringing society back in: symbols, practices, and institutional contradictions. In: Powell, W.W., DiMaggio, P.J. (Eds.), The New Institutionalism in Organizational Analysis. University of Chicago Press, Chicago, pp. 232-263.

Fuenfschilling, L., Truffer, B., 2014. The structuration of socio-technical regimes. Conceptual foundations from institutional theory. Res. Policy 43, 772-791.

Gas Transport Services, 2013. Rapport voorzieningszekerheid gas 2013. Available at, http://www.rijksoverheid.nl/documenten-en-publicaties/rapporten/2013/07/ 18/rapport-voorzieningszekerheid-gas-2013.html (Last accessed: September 23, 2013).

Gasunie, 2006. Biogas and others in natural gas operations (BONGO). A project under development. 23rd World Gas Conference, Amsterdam (Available at www.igu.org/ html/wgc2006/pdf/paper/add11732.pdf Last accessed: September 23, 2013).

Geels, F.W., 2002. Technological transitions as evolutionary reconfiguration processes: a multi-level perspective and a case-study. Res. Policy 31 (8-9), 1257-1274.

Geels, F.W., 2004. From sectoral systems of innovation to socio-technical systems: insights about dynamics and change from sociology and institutional theory. Res. Policy 33 (6/7), 897-920.

Geels, F.W., 2005. The dynamics of transitions in socio-technical systems: a multi-level analysis of the transition pathway from horse-drawn carriages to automobiles (1860-1930). Tech. Anal. Strat. Manag. 17 (4), 445-476.

Geels, F.W., 2006. Major system change through stepwise reconfiguration: a multi-level analysis of the transformation of American factory production (1850-1930). Technol. Soc. 28 (4), 445-476.

Geels, F.W., 2007. Analysing the breakthrough of rock "n" roll (1930-1970): multi-regime interaction and reconfiguration in the multi-level perspective. Technol. Forecast. Soc. Chang. 74 (8), 1411-1431.

Goldthau, A., 2014. Rethinking the governance of energy infrastructure: scale, decentralization and polycentrism. Energy Res. Soc. Sci. 1, 134-140.

Government 1, 2012. Interview Conducted in Person on October 18, 2012.

Government 2, 2012. Interview Conducted in Person on October 18, 2012.

Greenwood, R., Suddaby, R., 2006. Institutional entrepreneurship in mature fields: the big five accounting firms. Acad. Manag. J. 49 (1), 27-48.

Guston, D.H., 1999. Stabilizing the boundary between US politics and science: the role of the office of technology transfer as a boundary organization. Soc. Stud. Sci. 29 (1), 87-111.

Jolink, A., Niesten, E., 2012. Recent qualitative advances on hybrid organizations: taking stock, looking ahead. Scand. J. Manag. 28 (2), 149-161.

KEMA, 2010. Groen gas invoeding in het gasnet. Scenario ontwikkeling. Available at, http://www.agentschapnl.nl/sites/default/files/bijlagen/Groen\%20Gas\%20Invoeding\% 20in\%20het\%20Gasnet\%20-\%20Scenario\%200ntwikkeling.pdf (Last accessed: September 23, 2013).

Kislov, R., 2014. Boundary discontinuity in a constellation of interconnected practices. Public Adm. 92 (2), 307-323.

Kivimaa, P., 2014. Government-affiliated intermediary organisations as actors in systemlevel transitions. Res. Policy 43 (8), 1370-1380.

Kivisaari, S., Saari, E., Lehto, J., Kokkinen, L., Saranummi, N., 2013. System innovations in the making: hybrid actors and the challenge of up-scaling. Tech. Anal. Strat. Manag. 25 (2), 187-201.

Klerkx, Laurens, Leeuwis, C., 2008. Matching demand and supply in the agricultural knowledge infrastructure: experiences with innovation intermediaries. Food Policy 33 (3), 260-276.

Klerkx, L., Leeuwis, C., 2009. Establishment and embedding of innovation brokers at different innovation system levels: insights from the Dutch agricultural sector. Technol. Forecast. Soc. Chang. 76 (6), 849-860.

Klerkx, Laurens, Aarts, N., Leeuwis, C., 2010. Adaptive management in agricultural innovation systems: the interactions between innovation networks and their environment. Agric. Syst. 103 (6), 390-400.

Lieberherr, E., Truffer, B., 2015. The impact of privatization on sustainability transitions: a comparative analysis of dynamic capabilities in three water utilities. Environ. Innov. Soc. Transit. 15, 101-122.

Loorbach, D., Frantzeskaki, N., Thissen, W., 2010. Introduction to the special section: infrastructures and transitions. Technol. Forecast. Soc. Chang. 77 (8), 1195-1202.

March, James G., Olsen, Johan P., 1976. Ambiguity and Choice in Organizations. Universitetsforlaget, Bergen.

Markard, J., 2011. Transformation of infrastructures: sector characteristics and implications for fundamental change. J. Infrastruct. Syst. 17 (3), 107-117.

Markard, J., Raven, R., Truffer, B., 2012. Sustainability transitions: an emerging field of research and its prospects. Res. Policy 41 (6), 955-967.

Miller, C., 2001. Hybrid management: boundary organizations, science policy, and environmental governance in the climate regime. Sci. Technol. Hum. Values 26 (4), 478-500.

Ministry of Economic Affairs, 2012. Langetermijnbeleid over de gassamenstelling. March 12. Available at, http://www.rijksoverheid.nl/documenten-en-publicaties/kamerstukken/ 2012/03/13/kamerbrief-over-het-langetermijnbeleid-over-de-gassamenstelling.html (Last accessed: September 23, 2013).

National network 1, 2012. Interview Conducted in Person on November 22, 2012.

National network 2, 2012. Interview Conducted in Person on November 19, 2012.

National network 3, 2012. Interview Conducted in Person on November 19, 2012.

O'Mahony, S., Bechky, B.A., 2008. Boundary organizations: enabling collaboration among unexpected allies. Adm. Sci. Q. 53 (3), 422-459.

Platform Nieuw Gas, 2007. Vol gas vooruit. Available at, http://www.agentschapnl $\mathrm{nl} /$ sites/default/files/bijlagen/Vol\%20Gas\%20Vooruit\%20-\%20De\%20rol\%20van\% 20Groen\%20Gas\%20in\%20de\%20Nederlandse\%20energiehuishouding_0.pdf (Last accessed: September 23, 2013).

Platform Nieuw Gas, 2009. Van biogas naar groen gas. Opwaarderingstechnieken en leveranciers. Available at, http://www.agentschapnl.nl/sites/default/files/bijlagen/
Van\%20Biogas\%20naar\%20Groen\%20Gas\%20-\%200pwaarderingstechnieken\%20en\% 20leveranciers.pdf (Last accessed: September 23, 2013).

Platform Nieuw Gas, 2010. Nieuw Gas Krant, december 2010. Vijfkeerblauw, Den Haag.

Raven, R.P.J.M., 2004. Implementation of manure digestion and co-combustion in the Dutch electricity regime: a multi-level analysis of market implementation in the Netherlands. Energy Policy 32 (1), 29-39.

Raven, R., 2007. Co-evolution of waste and electricity regimes: multi-regime dynamics in the Netherlands (1969-2003). Energy Policy 35 (4), 2197-2208.

Raven, R.P.J.M., Verbong, G.P.J., 2009. Boundary crossing innovations: case studies from the energy domain. Technol. Soc. 31 (1), 85-93.

Reay, T., Hinings, C.R., 2009. Managing the rivalry of competing institutional logics. Organ. Stud. 30 (6), 629-652.

Regional network 3, 2012. Interview Conducted in Person on November 28, 2012.

Regional network/boundary shaker 1, 2013. Interview Conducted by Phone on January 9, 2013.

Regional network/boundary shaker 2, 2013. Interview Conducted by Phone on March 6 2013.

Rip, A., Kemp, R., 1998. Technological change. In: Rayner, S., Malone, E.L. (Eds.), Human Choice and Climate Change Vol. 2. Battelle Press, Columbus, OH, pp. 327-399.

RVO, 2011. Overzicht beleidsvraagstukken groen gas. Versnellerteam groen gas Werkdocument december 2011, Available at, http://groengas.nl/wp-content/ uploads/2011/09/beleidsvraagstukken-groen-gas-dec2011.pdf2011 (Last accessed: September 23, 2013).

RVO, 2012. Jaarbericht SDE +, SDE en MEP. Available at, http://www.agentschapnl.nl/ sites/default/files/Jaarbericht\%202011\%20SDE+\%20SDE\%20en\%20MEP\%20\% 5Bkleurenversie\%5D.pdf2012 (Last accessed: September 23, 2013).

RVO, 2014. Rapportage hernieuwbare energie. Deel 1: Implementatie 2003-2013 + jaarberichten SDE +, SDE, OV-MEP \& MEP 2013. Available at, http://www.rvo.nl/ sites/default/files/2014/06/Rapportage\%20hernieuwbare\%20energie\%202013.pdf (Last accessed: January 13, 2015).

Schippers, J.L., Verbong, G.P.J., 2000. De revolutie van Slochteren. In: Schot, J.W., Lintsen, H.W., Rip, A., de la Bruhèze, A. (Eds.), Delfstoffen, energie, chemie. Walburg Pers, Zutphen.

Schwarz, M., Thompson, M., 1990. Divided We Stand: Redefining Politics, Technology, and Social Choice. University of Pennsylvania Press, Philadelphia.

Seo, M.-G., Creed, W.E.D., 2002. Institutional contradictions, praxis, and institutional change: a dialectical perspective. Acad. Manag. Rev. 27 (2), 222-247.

Sine, W.D., David, R.J., 2003. Environmental jolts, institutional change, and the creation of entrepreneurial opportunity in the US electric power industry. Res. Policy 32 (2 SPEC), 185-207.

Smink, M.M., Hekkert, M.P., Negro, S.O., 2015. Keeping sustainable innovation on a leash? Exploring incumbents' institutional strategies. Bus. Strateg. Environ. 24 (2), 86-101.

Smith, A., 2007. Translating sustainabilities between green niches and socio-technical regimes. Tech. Anal. Strat. Manag. 19 (4), 427-450.

Thompson, N.A., 2013. Institutional logics and entrepreneurship (PhD thesis) Struggling for Legitimacy in the Emerging Bio-energy Field. Utrecht University.

Thornton, P.H., Ocasio, W., 1999. Institutional logics and the historical contingency of power in organizations: executive succession in the higher education publishing industry, 1958-1990. Am. J. Sociol. 105 (3), 801-843.

Thornton, P.H., Ocasio, W., 2008. Institutional logics. In: Greenwood, R., Oliver, C., Sahlin, K, Suddaby, R. (Eds.), The Sage Handbook of Organizational Institutionalism, pp. 99-129.

Thornton, P.H., Ocasio, W., Lounsbury, M., 2012. The institutional logics perspective. A New Approach to Culture, Structure, and Process. Oxford University Press, UK.

Tribbia, J., Moser, S.C., 2008. More than information: what coastal managers need to plan for climate change. Environ. Sci. Pol. 11 (4), 315-328.

Van Den Bergh, J.C.J.M., Truffer, B., Kallis, G., 2011. Environmental innovation and societal transitions: introduction and overview. Environ. Innov. Soc. Transit. 1 (1), 1-23.

Van Der Vooren, A., Alkemade, F., 2012. Managing the diffusion of low emission vehicles. IEEE Trans. Eng. Manag. 59 (4), 728-740.

Van Der Vooren, A., Alkemade, F., Hekkert, M.P., 2012. Effective public resource allocation to escape lock-in: the case of infrastructure-dependent vehicle technologies. Environ. Innov. Soc. Transit. 2, 98-117.

Van Lente, H., Hekkert, M.P., Smits, R.E.H.M., van Waveren, B., 2003. Roles of systemic intermediaries in transition processes. Int. J. Innov. Manag. 7 (3), 247.

Vandaag, Boerderij, 2009a. Leveren op gasnet geeft veel rendement, maar is lastig, September 23. p. 4

Vandaag, Boerderij, 2009b. Beursnieuws deel 2. Groen gas, November 13. p. 101.

Verbong, G., Geels, F., 2007. The ongoing energy transition: lessons from a socio-technical, multi-level analysis of the Dutch electricity system (1960-2004). Energy Policy 35 (2), 1025-1037.

Wesseling, J.H., Farla, J.C.M., Sperling, D., Hekkert, M.P., 2014. Car manufacturers' changing political strategies on the ZEV mandate. Transp. Res. Part D: Transp. Environ. 33 196-209.

Wesseling, J.H., Niesten, E.M.M.I., Faber, J., Hekkert, M.P., 2015. Business strategies of incumbents in the market for electric vehicles: opportunities and incentives for sustainable innovation. Bus. Strateg. Environ. http://dx.doi.org/10.1002/bse.1834 (in press).

Williams, P., 2002. The competent boundary spanner. Public Adm. 80 (1), 103-124.

Wirth, S., Markard, J., Truffer, B., Rohracher, H., 2013. Informal institutions matter: professional culture and the development of biogas technology. Environ. Innov. Soc. Transit 8, 20-41.

Yin, R.K., 2003. Case Study Research: Design and Methods. Sage Publications, Thousand Oaks, CA.

Zietsma, C., Lawrence, T.B., 2010. Institutional work in the transformation of an organizational field: the interplay of boundary work and practice work. Adm. Sci. Q. 55 (2), 189-221. 
Magda Smink, MSc is a PhD student at the section Innovation Studies at Utrecht University, the Netherlands. She studies the role of vested interests in sustainability transitions. Her main empirical field concerns the Dutch energy transition.

Dr. Simona Negro is an assistant professor at the section Innovation Studies at Utrecht University. She received her PhD in 2007 on the 'Dynamics of technological innovation systems - The case of biomass energy' at the Innovation Studies group. Her research aims to identify the activities and strategies performed by actors, such as entrepreneurs, incumbent players or policy makers, that contribute to the dynamics of innovation systems.

Dr. Eva Niesten is an assistant professor in economics of innovation at the section Innovation Studies at Utrecht University. She received her PhD in 2009 at the Rotterdam School of Management, Erasmus University. She held two postdoc positions; at the Florence Schoo of Regulation of the European University Institute and at the Netherlands Bureau for Economic Policy Analysis (CPB).

Prof. Dr. Marko Hekkert is a professor of Dynamics of Innovation Systems at Utrecht University. He is head of the section Innovation Studies at the Copernicus Institute of Sustainable Development. He coordinates research and education in the field of sustainable technology development and dynamics of technological innovation systems. He supervises several $\mathrm{PhD}$ students and post-docs on topics related to the transition to a sustainable energy system, and technological innovation systems. He has a background in Chemistry (MSc. 1995) and a PhD (2000) in energy and material systems modeling. 